\title{
An Attack on Inclusive Education in Secondary Education. Limitations in Initial Teacher Training in Spain
}

\author{
Manuel López-Torrijo ${ }^{*}$, Santiago Mengual-Andrés² \\ ${ }^{1}$ Department of Comparative Education \& History of Education, University of Valencia \{lopezm@uv.es\} \\ 2Department of Comparative Education \& History of Education, University of Valencia \{sanmenan@uv.es\} (D) \\ Received on 20 October; revised on 20 October; accepted on 10 November; published on 15 January 2015 \\ DOI: 10.7821/naer.2015.1.100
}

\begin{abstract}
Inclusive education is hard to implement in secondary schools. Probably, one of the determining factors lies in teachers' initial training that determines their attitude, identity and professional practice. This research analyses the initial teacher education programmes for Secondary Education, Higher Secondary Education, called bachillerato in Spain, and Vocational and Artistic training in the five best valued Spanish universities in the education field, according to the ranking I-UGR, after the European convergence process in the European Higher Education Area. The study analyses the national regulations that govern this training. A quantitative study was conducted to examine the number of credits dedicated to inclusive education and also a review of the contents of these subjects was carried out. The study concludes that this initial teacher training provides sufficient theoretical basis regarding the conceptualization of inclusive education and the skills to deal with the tutorship and academic and professional orientation. However, important limitations in training prevent future teachers from identifying students' and context's special educational needs, and the attention to diversity through different methods and curriculum adaptations.
\end{abstract}

KEYWORDS: TEACHERS, SECONDARY EDUCATION, INITIAL TRAINING, INCLUSIVE EDUCATION, SPAIN.

\section{THEORETICAL FRAMEWORK}

Inclusive education (IE) is presented unanimously and internationally as an ethical imperative that provides a real quality education to all students, taking into account their individual features and devoting no discrimination, equal opportunities, equity and universal accessibility principles (UNESCO, 2008). The IE starts from an inclusive culture, it is organised through the development of educational policies for everybody and it becomes evident in learning, participation and educational coexistence of all the members in the educational community (Booth et al. 2000). The real IE refers to, affects, involves and benefits all the members in the educational community. The IE understood as a professional and social attitude guarantees the inalienable right of every human being to have a complete personal and social development and set the bases of a real inclusive society.

\footnotetext{
*To whom correspondence should be addressed:

Facultad de Filosofía y Ciencias de la Educación

Universidad de Valencia

Avda. Blasco Ibáñez, 30, 46010

Valencia, Spain
}

In 1978 the Warnock report already announced that no improvement would take place in the so called "educational integration" without the necessary teacher training (Warnock, 1978). It also recommended that all teacher training courses including postgraduate courses- included training components referring to it. Therefore, the Salamanca Statement (UNESCO, 1994) urged to assure that teacher training programmes, both initial and in-service training, were addressed to deal with the special educational needs in mainstream schools. In 1996 the Charter of Luxembourg of the European Union stated that successful inclusive education involved enhaced initial and inservice training for all the teachers which lead to recognised qualifications (HELIOS II, 1996). On the other hand the UN Convention on the Rights of Persons with Disabilities (UN, 2006) explains that this training is one of the "rights recognized in this Convention so as to better provide the assistance and services guaranteed by those rights" (Art 4.1.9), and also that it "shall incorporate disability awareness" (Art 24.4). More recently, the 48th session of the International Conference on Education with the theme Inclusive Education: The way of the future (2008) urges to improve the status and working conditions of teachers. It points out the convenience of improving their selection based on their qualifications and awareness about special and educational needs and also recommends:

17. To train teachers providing them with the necessary skills and resources to teach diverse student populations and to satisfy the different learning needs in the different categories of pupils. We can provide them with these by methods like the professional development as for the school, initial training on inclusion and an instruction in which the development and the strength of each pupil were taken into account.

18. "To support both the strategical role of the Higher Education in initial training and also teachers' professional training about inclusive educational practices through the adequate resources assignment, among others."

Later, the European Agency for Special Needs and Inclusive Education (EADSNE, 2011) detected this training necessity, specially related to Secondary Education, and highlighted it as one of the basic causes of the inadequate implementation of IE, mainly in this school level.

However, teacher training is not a merely individual task, but a process of improvement of schools and professional development that must reach new roles and tasks, among which 
inclusive education may be one of the richest and most complicated ones. Therefore, training has to take into account not only the students' needs, but also the limitations (e.g., cultural, political, economic) that secondary schools suffer (Arnáiz, 2003).

Recent research has shown how initial training on IE is determining for its success (Avramidis, \& Norwich, 2002; Carpenter \& Cai, 2011; Cook 2002; Jiménez-Monteagudo \& Hernández-Álvarez, 2013; Mu et al. 2007; Sharma et al. 2006). Specific training on IE improves future teachers' attitudes and confidence and reduces their concerns (Glumbic et al. 2004; Stella et al. 2007). It also helps to improve their skills and the self-reflection about their own abilities to carry out IE (Cologon, 2012). Specially, it is highlighted the importance of having the adequate knowledge about the different disabilities (Brandes et al. 2012; de Boer et al. 2010; Sharma et al. 2008), the training on special education in graduate and postgraduate courses (Forlin et al. 2010; Sharma et al. 2009), and also the training on inclusive policies and legislation (Forlin et al. 2007). In fact, attitudes towards IE improve in graduate students with better qualifications (Forlin et al. 2009; Sharma et al. 2006), and as they move forward in their training. Some studies have detected the training areas that pre-service teachers are most worried about: the attention to low achieving students, disaffection, antisocial and unhealthy behaviours, and very specially the bullying (Kyriacou et al. 2013).

On the other hand, there is a great number of studies that prove the lack of training that the IE professionals report (Cook, 2002; Forlin \& Chambers 2011; Forlin et al. 2010; Forlin et al. 2009; Gokdere 2012; Lambe, 2011; Oliveira and Souza, 2011; Sharma et al. 2009). In the case of Spanish population, Sandoval (2009) found training lacks related to identifying learning disabilities, teachers' responsibilities and the cooperation among teachers.

At the same time, it is assumed the need of investing in teachers' specific training on IE, in the multidisciplinary support, in the curriculum differentiation, in infrastructures and in the participation of all the educational community (Raimundo Martins, 2014; Silva, 2013; Vitalino, 2007). It has been also proved the need of dealing with a provision of services and a previous training, both interdisciplinary, among the areas of health, social services and education (Tetreault et al., 2012).

In the same way, it has been shown the possibility of implementing effective methodologies for the development of a real IE. In this respect, we can take into account the proven results when applying methodologies based on Freire, like: the constructive-collaborative model (Duek, 2014); the training model based on the Theory of Subjectivity of González Rey and the concept of creativity of Mitjans Martínez (Vieira \&Lucía, 2013); the learning objectives that count on a strategy of distance training (Bardy et al., 2013). It also has been carried out significant attempts to perform specific professional tasks related to IE, like the approach of historical-cultural psychology, based on Vitgotski's theories and developed for the psychologists' professional practice (Barroco \& Souza, 2012).

\section{INITIAL SECONDARY EDUCATION TEACHER TRAINING IN SPAIN}

\subsection{The Regulatory Framework}

The right to education is included in the Spanish Constitution, in the Art 27. In a more explicit way, the Art 49 highlights the right to "prevention, treatment, rehabilitation and integration of physically, sensory, and mentally handicapped people". Later, this basic right was developed in the Law for the Social Integration of the Disabled (LISMI, 1982) and by a valuable normative process towards a truly inclusive education (LópezTorrijo, 1992). Nowadays the Organic Law for Improvement of Quality in Education (LOMCE, 2013) assumes the important commitment that the former law, the Organic Law of Education (LOE, 2006) raised with regard to IE. However, no significant progress has been found, despite the fact that $26.5 \%$ of students do not finish the Compulsory Education successfully.

With regard to the initial Secondary Education teacher training, the enactment of the Organic Law of General Organisation of the Educational System (LOGSE, 1990) raised that the Secondary Education teachers' skill levels stopped being exclusively propaedeutic for the university, when ordering that Compulsory Secondary Education (ESO) is a general, basic, compulsory and free level. This involved that Secondary Education teachers' roles were similar to those of Primary Education and it supposed a new challenge that most Secondary Education teachers did not feel prepared for.

To cover this initial training various courses were offered for those who wanted to become teachers after finishing their university education. This offer provided a poor instructional and educational psychology training with the so called course, Couse of Pedagogial Aptitude (CAP), or the so called course, Pedagogial Aptitude Certificate (CCP). These qualifications were regulated by the General Law of Education and Financing of the Educational Reform (LGE, 1970) and by the Ministerial Order of 8 July 1971 and they included 159 hours of theoretical training on "1) Principles, objetives and problems of Education in its psychological, sociological and historical aspects; 2) Technology and educational innovation systems; 3) Special education teaching" (second Art). A second stage of 150 hours included a teaching practicum "in the secondary schools that each Institute of Education Sciences determines (...) with two or three different tutors of the corresponding education area" (Art. 3). The inadequate and unsuitable character of this training created a general dissatisfaction. However, the so desired reform was being put off because of financial disagreements between the Ministry of Education and the Ministries of Education in Regional Governments; because of some lack of definition on behalf of the agents in charge of this initial training; because of some associative pressures, and because of the lack of agreement between the different political trends (Barberá, 2010).

The enactment of the LOE (2006) and the incorporation of Spain to the European Higher Education Area (EHEA) developed a new model of instructional and educational psychology training in the form of a postgraduate course for the future Secondary Education teachers of the different teachingrelated areas (Tiana, 2013). The Royal Decree 1393/2007 and the subsequent Resolution of 17 December 2007 regulated this new qualification.

\subsection{Conditions of the New Initial Secondary Education Teacher Training Programme}

The central government set the conditions to which the corresponding curricula have to adapt to in order to qualify teachers for the professional practice. Moreover, they have to meet current European regulations. Universities have to adapt curricula to the national regulations in order to obtain the professional competencies assigned by the government (Royal Decree 1393/2007, Art 12.9 and 15.4). 
To gain access to this Master's degree it is indispensable to give credit for the achieved competencies related to the specialization the student wants to study, by doing a test designed by universities or by having completed any of the university degrees corresponding to the specialization chosen. Likewise, the student will have to give credit for the fluency in a foreign language, equivalent to the B1 level of the Common European Framework of Reference for Languages (s. 4.2).

Master's degrees will have a duration of 60 European credits. The $80 \%$ of them will be on-site training, including necessarily the Practicum in this obligation (s. 5).

Apart from the general instructional and pedagogical objectives (Order ECI/3858/2007, annex, s. 3), the Master's degree includes specific ones, such as "the development and implementation of individual and group instructional methods adapted to students' diversity" (s. 3.4); "the design and development of learning environments with special attention to equity" (s. 3.5); and "the development of tasks of tutorship and students' guidance in a collaborative and coordinated way" (s. 3.8).

The courses are composed of, at least, the next modules (Table 1):

Table 1. Minimum modules, subjects and European credits of the curriculum leading to obtain the Master's degree that qualifies to practice the regulated professions of Compulsory Secondary Education teacher, Bachillerato teacher, Vocational Training teacher and Language teacher. Own drawing up from the Order ECI/3858/2007, 27 December.

\begin{tabular}{|c|c|c|}
\hline & Module & $\begin{array}{c}\text { Number of } \\
\text { European } \\
\text { credits }\end{array}$ \\
\hline \multicolumn{2}{|r|}{ Generic } & \multirow{3}{*}{12} \\
\hline \multirow[b]{2}{*}{ Subjects } & $\begin{array}{l}\text { Learning and personality develop- } \\
\text { ment. }\end{array}$ & \\
\hline & $\begin{array}{l}\text { Educational processes and contexts } \\
\text { Society, family and education }\end{array}$ & \\
\hline \multicolumn{2}{|r|}{ Specific } & \multirow{4}{*}{24} \\
\hline \multirow{3}{*}{ Subjects } & $\begin{array}{l}\text { Complements for disciplinary train- } \\
\text { ing. }\end{array}$ & \\
\hline & $\begin{array}{l}\text { Learning and teaching of the special- } \\
\text { ised subjects }\end{array}$ & \\
\hline & $\begin{array}{l}\text { Teaching innovation and introduction } \\
\text { to educational research }\end{array}$ & \\
\hline \multicolumn{2}{|r|}{ Practicum } & \\
\hline \multicolumn{2}{|c|}{$\begin{array}{l}\text { Practicum in the specialisation, including the Final } \\
\text { Master's Degree Project }\end{array}$} & 16 \\
\hline \multicolumn{2}{|c|}{ Free choice ECTS credits } & 8 \\
\hline
\end{tabular}

A first assessment of the programme shows the scanty space dedicated to basic pedagogical training: 12 ECTS credits against the 24 dedicated to specific teaching. Given that most of the contents referring to IE are in the so called generic module, it is obvious the lack of credits to provide the necessary training. This implies that and adequate initial training of future Secondary Education teachers with regard to IE will lack from the beginning.

As for the competencies related directly to IE, the national regulation states the following (Table 2):
Table 2. List of competencies directly related to IE stated in the Order ECI/3858/2007, 27 December

\begin{tabular}{|c|c|c|}
\hline Module & Credits & Competencies related to IE \\
\hline Generic & 12 & $\begin{array}{l}\text {-To know students' characteristics, social } \\
\text { contexts and motivations. } \\
\text {-To understand the development of students' } \\
\text { personality and the possible dysfunctions that } \\
\text { affect learning. } \\
\text {-To identify and plan the resolution of educa- } \\
\text { tional situations that affect students with differ- } \\
\text { ent abilities and learning paces. } \\
\text {-To know and implement resources and infor- } \\
\text { mation, tutorship, and academic and profession- } \\
\text { al orientation strategies. } \\
\text {-To participate in the definition of the educa- } \\
\text { tional project and in the school general activi- } \\
\text { ties taking into account quality improvement, } \\
\text { attention to diversity, learning problems preven- } \\
\text { tion and coexistence criteria. } \\
\text {-To relate education with the environment and } \\
\text { to understand the educative role of family, } \\
\text { community,etc. in the education of respect for } \\
\text { rights and liberties, ....and equal treatment and } \\
\text { no discrimination of disabled people. }\end{array}$ \\
\hline Specific & 24 & $\begin{array}{l}\text {-To know the contexts and situations where } \\
\text { different curriculum contents are used or im- } \\
\text { plemented. }\end{array}$ \\
\hline
\end{tabular}

The academic perspective, specially extended in the secondary education level, assumes that the main condition to be a good teacher is to have a deep knowledge of the contents of a subject. However, we remind some of the education principles that the LOMCE states in the beginning of its articles:

Art 1 A) Education quality for all the students, no matter their conditions or circumstances.

B) The equity that assures equal opportunities for the complete personality development through education, inclusive education, equal rights and opportunities that help to overcome any discrimination and universal accessibility, and that they act as a compensatory element in personal, cultural, economic and social inequalities, with special attention to those that come from any type of disability.

E) Flexibility to adapt education to students' diverse abilities, interests, expectations and needs as well as to adapt to the changes that students and society experience.

From these basic approaches, it is surprising the absence, among others, of specific competencies -both in the generic and specific module and specially in the practicum- that specify teachers' ability to:

- Know the philosophy, principles, conditions and implications of IE.

- Value the normative development in educational policies, highlighting their contributions and lacks to reach a real IE.

- Have a detailed knowledge of the different personal, social, economic barriers, etc. that difficult the access to learning, participation and educational coexistence of everybody in equity. 
- Qualify to give an educational response to student diversity through the planning and adaptation of the curriculum, cooperative learning methodologies, individualised attention, monitoring strategies, and continuous and personalised assessment, etc.

- Qualify for the collaborative teaching.

- Guide the family, the educational community and the different educational contexts, and also to favour the participation of all of them in a participative IE project.

Undoubtedly, these skills can hardly be practised if we do not overcome the view of the teacher as a mere transmitter of knowledge and we assure his real identity: a professional that researches, thinks about his practice and improves it within an educational organization; and he, more than a technician, is a critical intellectual aware of the ethical dimension of his profession (Arnaiz, 2003).

\subsection{Analysis of some Master's Degrees on Secondary Education}

The Decree 1393/2007 and the Order ECI/3858/2007 let the universities the authority of planning their respective Master's degrees on Secondary Education within a regulatory framework. This has allowed them a great level of flexibility and of ability to act (Tiana, 2013).

As an approach to the practical realization of these training plans, we have selected for this study the five best valued Spanish universities in the Education field, according to the rankings I-UGR during the last three periods, as table 3 shows.

Table 3. Spanish universities classification in the education field, according to the ranking I-UGR

\begin{tabular}{cccc}
\hline & $\begin{array}{c}\text { 3rd Edition. } \\
\text { Period 2007- } \\
\text { 2011 }\end{array}$ & $\begin{array}{c}\text { 4th Edition. } \\
\text { Period 2008- } \\
\text { 2012 }\end{array}$ & $\begin{array}{c}\text { 5th Edition. } \\
\text { Period 2009- } \\
\text { 2013 }\end{array}$ \\
\hline $\begin{array}{c}\text { University of } \\
\text { Granada }\end{array}$ & $3 \mathrm{rd}$ & $1 \mathrm{st}$ & $1 \mathrm{st}$ \\
$\begin{array}{c}\text { University of } \\
\text { Valencia }\end{array}$ & $1 \mathrm{st}$ & $2 \mathrm{nd}$ & $2 \mathrm{nd}$ \\
$\begin{array}{c}\text { University of } \\
\text { Barcelona }\end{array}$ & 8th & 4 th & $3 \mathrm{rd}$ \\
$\begin{array}{c}\text { Complutense } \\
\text { University of } \\
\text { Madrid }\end{array}$ & 5 th & 5 th & 4 th \\
University of \\
Alicante
\end{tabular}

Through the study of the curricula designed in these universities we try:

- To know and compare the credits dedicated to the training on IE contents in the different universities.

- To analyse the contents related to IE that are offered in the corresponding Master's degrees, basically regarding three specific fields: IE conceptual framework; curriculum adaptations; tutorship and academic and professional orientation.

- To analyse and compare the necessary skills to carry out an adequate IE.

- To assess and discuss the convenience of contents and skills offered to achieve an adequate initial training on IE in future teachers that complete the Master's degree on Secondary Education in the five universities listed above.

\subsubsection{Structure of the Modules and Credits in the Five Universities}

As said before, the national regulation that governs the Master's degrees on Secondary Education raised a minimum common structure for all the national territory and let the universities the assignment of up to eight free choice credits.

Figure 1 summarises the assignment that each university has done with the aforementioned free choice credits.

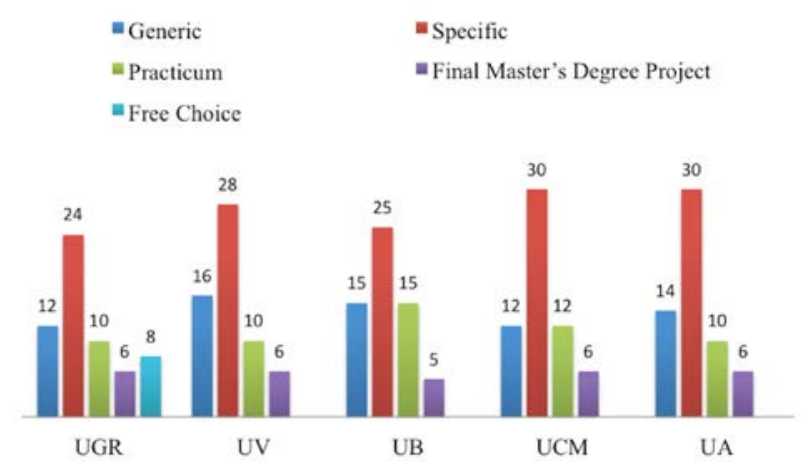

Figure 1. Credits structures and modules assigned by the Universities of Granada, Valencia, Barcelona, Complutense of Madrid and Alicante in the Master's degree on Secondary Education.

The University of Granada is the only university that kept the structure suggested by the Ministry and has used the free choice credits to design five elective subjects. Each of them has four credits. Students have to choose two from the five subjects. The five optional subjects suggested are: Attention to diversity and multiculturalism; Attention to students with special needs; Education for equality; Towards a culture of peace; Organization and management of educational centres. The three first subjects suppose a direct and extremely valuable contribution to training on IE. This turns the University of Granada into the university with the most complete and adequate curriculum for the students' attention to diversity. However, the fact that these subjects are optional does not assure this training.

The second university in the ranking -the University of Valencia- has decided to distribute the free choice credits among the generic and specific modules assigning four credits to each of them. This kind of "Solomon distribution" reaffirms the Ministry criteria, highlighting the theoretical training. However, it says nothing about a specialization in any specific field. The IE issue in this Master's degree has the similar inattention conditions that the suggested by the Ministry.

The University of Barcelona also dedicates the free choice credits to increase the structure suggested by the Ministry, but with a different assignment: it increases the generic module in three credits and the specific module in one; it raises the size of the practicum until 10 credits and reduces the Final Master's Degree Project to five credits. In all, it dedicates half of the free choice credits to theoretical training, mainly in the generic module and, specially, it highlights the importance of practical training, granting to it the $16.5 \%$ of the Master's degree. Neither this supposes a certain and specific contribution to training on IE.

The fourth university in the ranking -the Complutense University of Madrid- has dedicated the eight free choice credits to increase the specific module of specialised teaching in six credits and the practicum in two credits. It shows a clear leaning towards the deepening of the specialist teacher's task in the 
teaching of the contents of his speciality, with a practical training.

For its part, the University of Alicante increases the generic module in two credits and the specific module in six credits with an assignment of subjects that will be analysed in the following section.

\subsubsection{Description of the Contents Dedicated to Topics Related to IE}

A more detailed reading of the syllabus of each subject allows us to define, at least in a theoretical level, the specific contents that deal with IE in some of its integral contents. Table 4 summarises these contents.

Among many aspects and contents necessary for a complete training on IE, we selected three as a base for an approach to an evaluative analysis of the contents: the conceptualization of IE; the diversity of curriculum adaptations as a measure and tool of attention to diversity; and the tutorship and guidance as the base of student's individualised attention and socialization.

In a first approach, table 5 shows the presence that these issues have in the subject contents offered in the Master's degrees on Secondary Education of the five universities.

It is well known that the presence of a specific content in a syllabus does not guarantee its complete dealing; and, in the same way, its absence does not exclude the allusions to it either. To deduce exact conclusions, it would be necessary a thorough analysis of a significant number of groups in which teaching is being developed in each Master's degree. However, table 5 shows important assessments.

With regard to the first aspect, related to the conceptualization of IE, all the universities address it in one way or another. The University of Granada offers a wide range of contents on this matter, making it conditional, however, to the students' enrolment in, at least, one of the three elective subjects previously described. For its part, the University of Valencia addresses inclusive education in two different subjects: "Society, family and education" and "Educational processes and contexts". The University of Barcelona raises the IE paradigm but it does not detail the conceptualization of students with educational support needs and with specific educational needs. The Complutense University of Madrid does consider in its syllabi the inclusive paradigm and the conceptualization of students' diverse needs. Finally, the University of Alicante adds to the theoretical framework the psychoeducational intervention for visual, hearing and motor (spina bifida and cerebral palsy) impairments, for pervasive developmental disorders (autistic and Asperger disorders), for attention deficit hyperactivity disorder (ADHD), and for mental retardation and giftedness.

With regard to the second aspect, "curriculum adaptation", we find it is the most incomplete. Initially, none of the five universities addresses the practical implementation of curriculum adaptations in the classroom. They just deal with some levels of curriculum design in a theoretical way. The University of Granada and the University of Valencia do not determine in their syllabi the levels of curriculum adaptation and the University of Alicante does it partially. Finally, the University of Barcelona and the Complutense University of Madrid do not make any specific allusion to curriculum adaptations or to levels of curriculum design.

The aspect most tackled is the one related to "tutorship and academic and professional orientation" which is addressed in the five universities.

\subsubsection{Addressing Generic Competencies Related to Inclusive Education}

Another perspective of this analysis is provided by the level of development of the basic skills related to IE included in the Order ECI/3858/2007, 27 December. Table 6 summarises the treatment that these skills have in the planning of the different Master's degrees. However, we have to remember, once again, that the simple fact of mentioning these skills in the syllabi does not confirm its realization through the programmed learnings.

Again, this table shows how the theoretical descriptions of the different circumstances that involve educational needs in students are addressed. Only some Master's degrees include the specific skills to identify and plan students' attention due to these circumstances.

The competence that is addressed the least is the one related with the adoption of measures and resources that the School Educational Project has to incorporate to deal with students' diversity. And this is, undoubtedly, one of the basic pieces of an inclusive project.

The competencies related to tutorship, orientation and family participation are well treated in the majority of the Master's degrees analysed.

Table 5. Description of the contents related to IE addressed in the different subjects of the Master's degrees on Secondary Education offered by the Universities of Granada, Valencia, Complutense of Madrid, Barcelona and Alicante.

\begin{tabular}{|c|c|c|}
\hline University & Subjects & Contents related to IE \\
\hline \multirow{6}{*}{$\begin{array}{l}\text { University of } \\
\text { Granada }\end{array}$} & $\begin{array}{l}\text { Learning and personality develop- } \\
\text { ment (4 ECTS) }\end{array}$ & \\
\hline & $\begin{array}{l}\text { Educational processes and contexts } \\
\text { (4 ECTS) }\end{array}$ & -Levels of curriculum design, their elements and functions. \\
\hline & $\begin{array}{l}\text { Society, family and education } \\
\text { (4 ECTS) }\end{array}$ & $\begin{array}{l}\text {-Educational function of the family. } \\
\text { - The family-educational institution relationship: the tutorial function and the commu- } \\
\text { nicative processes between family and school. }\end{array}$ \\
\hline & $\begin{array}{l}\text { Attention to diversity and multicul- } \\
\text { turalism. } \\
\text { (Elective subject: } 4 \text { ECTS) }\end{array}$ & (no public information about the contents available) \\
\hline & $\begin{array}{l}\text { Attention to students with special } \\
\text { needs } \\
\text { (Elective subject: } 4 \text { ECTS) }\end{array}$ & (no public information about the contents available) \\
\hline & $\begin{array}{l}\text { Education for equality } \\
\text { (Elective subject: } 4 \text { ECTS) }\end{array}$ & (no public information about the contents available) \\
\hline
\end{tabular}


Table 5. (continued)

\begin{tabular}{|c|c|c|}
\hline \multirow{3}{*}{$\begin{array}{l}\text { University of } \\
\text { Valencia }\end{array}$} & $\begin{array}{l}\text { Learning and personality develop- } \\
\text { ment (4 ECTS) }\end{array}$ & - Learning disorders and difficulties. \\
\hline & $\begin{array}{l}\text { Educational processes and contexts } \\
\text { (8 ECTS) }\end{array}$ & $\begin{array}{l}\text { - Levels of curriculum design. Curriculum adaptations. } \\
\text { - Orientation and tutorship as teaching function dimensions. Regulatory rules. Depart- } \\
\text { ment of Orientation. Tutor's functions. Orientation plan. Tutorial action plan. } \\
\text { - Attention to diversity. Conceptual framework: special educational needs and educa- } \\
\text { tional support needs. Regulatory rules. Attention to diversity measures and pro- } \\
\text { grammes. Attention to diversity plan. }\end{array}$ \\
\hline & $\begin{array}{l}\text { Society, family and education } \\
\text { (4 ECTS) }\end{array}$ & $\begin{array}{l}\text { - Sociological analysis of educational inequalities and diversity. } \\
\text { - The school as a social subsystem. } \\
\text { - Education for equality and diversity. }\end{array}$ \\
\hline \multirow{4}{*}{$\begin{array}{l}\text { University of } \\
\text { Barcelona }\end{array}$} & $\begin{array}{l}\text { Secondary } \quad \text { Education r students' } \\
\text { learning and development (5 ECTS) }\end{array}$ & $\begin{array}{l}\text { - Changes in the educational situations and actions to improve the learning and to } \\
\text { address diversity. }\end{array}$ \\
\hline & $\begin{array}{l}\text { Educational processes and contexts } \\
(2.5 \text { ECTS) }\end{array}$ & $\begin{array}{l}\text { - Diversity. Diversity as a reality, as richness. Strategies to identify diversity. Re- } \\
\text { sources to deal with diversity. }\end{array}$ \\
\hline & $\begin{array}{l}\text { Society, family and education } \\
\text { (5 ECTS) }\end{array}$ & - \\
\hline & $\begin{array}{l}\text { Tutorship and orientation }(2,5 \\
\text { ECTS) }\end{array}$ & $\begin{array}{l}\text { - The teaching, tutorial and orientation function. } \\
\text { - From diversity to inclusion. } \\
\text { - Academic and professional orientation } \\
\text { - The tutorial action plan and teaching planning }\end{array}$ \\
\hline \multirow{3}{*}{$\begin{array}{l}\text { Complurense } \\
\text { Univesity of Madrid }\end{array}$} & $\begin{array}{l}\text { Learning and personality develop- } \\
\text { ment. } \\
\text { (4 ECTS) }\end{array}$ & $\begin{array}{l}\text { - Educational psychology fundamentals and strategies of educational diversification. } \\
\text { - Identification and interventions for learning problems in Secondary Education. }\end{array}$ \\
\hline & $\begin{array}{l}\text { Educational processes and contexts } \\
\text { (4 ECTS) }\end{array}$ & $\begin{array}{l}\text { - Attention to diversity in Compulsory Secondary Education. Factors of diversity. } \\
\text { Attention to diversity.models. Ordinary and extraordinary measures in the Spanish } \\
\text { Education System. } \\
\text { - Tutorship and academic and professional orientation in Secondary Education. Tutori- } \\
\text { al action plan. Academic and professional orientation plan. }\end{array}$ \\
\hline & $\begin{array}{l}\text { Society, family and education } \\
\text { (4 ECTS) }\end{array}$ & - Family orientation in the Secondary Education context. \\
\hline \multirow{4}{*}{$\begin{array}{l}\text { University } \\
\text { Alicante }\end{array}$} & $\begin{array}{l}\text { Learning and personality develop- } \\
\text { ment. ( } 3 \text { ECTS) }\end{array}$ & ( \\
\hline & $\begin{array}{l}\text { Curriculum design and adaptation. } \\
\text { (5 ECTS) }\end{array}$ & - Structure of the curriculum design. \\
\hline & $\begin{array}{l}\text { Learning and developmental disor- } \\
\text { ders in adolescents } \\
\text { (3 ECTS) }\end{array}$ & $\begin{array}{l}\text { - Sensory and motor disorders in adolescents. } \\
\text { - Development and behaviour disorders. } \\
\text { - School maladjustment. Tutorship. } \\
\text { - Intellectual disability and giftedness. } \\
\end{array}$ \\
\hline & $\begin{array}{l}\text { Society, family and education } \\
\text { (3 ECTS) }\end{array}$ & $\begin{array}{l}\text { - Education social functions } \\
\text {-Educational function of the family. } \\
\text { - The family-educational institution relationship: the tutorial function. Family back- } \\
\text { ground and school success. }\end{array}$ \\
\hline
\end{tabular}

Table 6. Presence of IE conceptualisation, curriculum adaptations, and tutorship and orientation in the contents of the Master's degrees on Secondary Education

\begin{tabular}{lll}
$\begin{array}{l}\text { Inclusive Education and conceptual framework of ANEAE } \\
\text { (Students with Specific Needs of Educational Support) }\end{array}$ & Curriculum adaptations & $\begin{array}{l}\text { Tutorship and academic } \\
\text { and professional orienta- } \\
\text { tion }\end{array}$ \\
\hline
\end{tabular}

University of Yes, when any of the two elective subjects on Inclusive Educa- Yes, without specifying

lum design

Yes, without specifying until what level of curriculum design

\begin{tabular}{cl}
$\begin{array}{c}\text { University of } \\
\text { Valencia }\end{array}$ & Yes, in two different subjects \\
$\begin{array}{c}\text { University of } \\
\text { Barcelona }\end{array}$ & $\begin{array}{c}\text { Yes, as diversity. It does not raise the concepts of ANEAE } \\
\text { (Students with Specific Needs of Educational Support) and/or } \\
\text { AcNEE (Students with special educational needs) }\end{array}$ \\
$\begin{array}{c}\text { Complutense } \\
\text { University of } \\
\text { Madrid }\end{array}$ & \\
$\begin{array}{c}\text { University of } \\
\text { Alicante }\end{array}$ & $\begin{array}{c}\text { Yes, as a conceptual framework and intervention for the different } \\
\text { disabilities }\end{array}$ \\
\hline
\end{tabular}

No, it only deals with the second level of curriculum design

\begin{tabular}{ll} 
No & Yes \\
\hline No & Yes \\
\hline
\end{tabular}

Yes

Yes

- 
Table 7. Development of the basic competencies included in the Order ECI/3858/2007, 27 December in the different Master's degrees

\begin{tabular}{|c|c|c|c|c|c|}
\hline Skills & UGRA & UV & UB & UCM & UA \\
\hline To know students' characteristics, social contexts and motivations. & $\begin{array}{l}\text { Yes, elec- } \\
\text { tive subject }\end{array}$ & Partial & Yes & Yes & Yes \\
\hline $\begin{array}{l}\text { To understand the development of students' personality and the possible dysfunctions that } \\
\text { affect learning. }\end{array}$ & $\begin{array}{l}\text { Yes, elec- } \\
\text { tive subject }\end{array}$ & Partial & Yes & Yes & Yes \\
\hline $\begin{array}{l}\text { To identify and plan the resolution of educational situations that affect students with different } \\
\text { abilities and learning paces. }\end{array}$ & $\begin{array}{l}\text { Yes, elec- } \\
\text { tive subject }\end{array}$ & Partial & Partial & Partial & Yes \\
\hline $\begin{array}{l}\text { To know and implement resources and information, tutorship, and academic and professional } \\
\text { orientation strategies. }\end{array}$ & Yes & Yes & Yes & Yes & Yes \\
\hline $\begin{array}{l}\text { To participate in the definition of the educational project and in the school general activities, } \\
\text { taking into account quality improvement, attention to diversity, learning problems prevention } \\
\text { and coexistence criteria. }\end{array}$ & Partial & Yes & Partial & Partial & Partial \\
\hline $\begin{array}{l}\text { To relate education with the environment and understanding the educational function of } \\
\text { family, community, ...in the education of respect of rights and liberties, .....and in the equality } \\
\text { of treatment and no discrimination of disabled people. }\end{array}$ & Partial & Yes & Partial & Yes & Yes \\
\hline
\end{tabular}

\section{DISCUSSION}

Despite the fact that the criterion argued in the creation of the EHEA is the convergence of future professionals training, in the history of the Spanish university we have never designed and put into practice any curricula as diverse as the current ones. This lack of affinity is specially clamorous in the development of graduate courses, but we can also find it in postgraduate courses.

It is fair to declare that the importance that national and international policies, research and teachers' feelings attributed to Secondary Education teacher training has led to the increase of the training hours by the development of a Master's degree on Secondary Education compared to the previous training models (CAP and CCP). Those plans had 300 hours, while the actual plans have 60 ECTS.

However, it is also true that in the current Master's degree we can still see the teacher as a transmitter of knowledge of his specific area. This is proved by the, at least, 24 ECTS dedicated to specific didactics, against the 12 dedicated to generic training.

The contents and skills raised in this field do not advocate teacher identity as an intellectual aware of the ethical dimension of his profession, an intellectual that researches and improves his practice from a critical and collaborative reflection.

Although we have moved forward as for the training on contents and skills necessary to carry out a real IE, this advance is still inadequate. The theoretical conceptualization of IE is, just partly, taken into account. Some universities raise contents related to the identification of some special educational needs. The development of tutorship and academic and professional orientation is dealt in a theoretical but general way. The attention to families is also starting to be considered, but not their training for their participation in the process and in the educational community. Nevertheless, training on instructional and and organizational strategies necessary to carry out IE is not provided. Attention to students with behavioural disorders, ethnic minorities, socially marginalised groups or collectives that live in unfavourable social, family or cultural environments is not addressed urgently and roundly. Only some programmes include multiculturalism. Attention to students-with high abilities is hardly mentioned. The regulatory development that implements IE is not presented and teachers are not trained for its professional assessment.Professionals are not prepared for a real collaborative teaching, which is the basis of a collaborative learning.

To sum up, initial Secondary Education teacher training on topics related to attention to diversity is insufficient and it compromises the development of a real IE in a radical and basic way. As research shows, this will negatively affect teachers' attitudes, abilities and professional self-perception.

\section{CONCLUSIONS}

Despite the quantitative increase in training, the reforms in initial Secondary Education teacher training carried out in Spain within the EHEA framework offer an inadequate preparation of future teachers with regard to the performance of their duties as the main agents of IE. This supposes one of the hardest attacks to the future development of IE, precisely in the level with highest school failure: Secondary Education.

Moreover, to promote inclusive schools, cultural, political, economic, and social barriers that some Secondary Education students suffer should be eliminated.

It is necessary to rebalance Secondary Education teachers' professional training by increasing their specialization as agents that promote comprehensive and equitable schools, and that eliminate the barriers that prevent students from accessing to learning, and to educational participation and coexistence.

It is necessary to guarantee teachers' identity as autonomous, critical, collaborative and supportive educators that have an ethical commitment that assures the right to quality education for all the students.

In conclusion, it is essential to assure the adequate teacher training on the cultures, policies and practices of IE in order to obtain similar results regarding IE that those already achieved in 
primary schools and in order to set the bases of a real inclusive society.

\section{REFERENCES}

Arnaíz, P. (2003). Educación inclusiva: una escuela para todos. Málaga: Aljibe.

Avramidis, E., \& Norwich, B. (2002). Teachers' attitudes towards integration / inclusion: a review of the literature. European Journal of Special Needs Education, 17(2), 129-147. doi: 10.1080/08856250210129056

Barberá, O. (2010). De nuevo la formación consecutiva y de nuevo el menosprecio a la formación simultánea. In I. González (Coord.), El nuevo profesor de secundaria: La formación inicial del docente en el marco del Espacio Europeo de Educación Superior (pp. 89-95). Barcelona: Graó.

Bardy, L. R., Hayashi, M. C., Schlünzen, E. T. M. et al. (2013). Objects for Learning as educational resources in inclusive contexts: support for distance teacher education. Revista Brasileira de Educação Especial, 19(2), 273-288. doi: 10.1590/S1413-65382013000200010

Barroco, S. M. S., \& Souza, M. P. R. de (2012). Historical-cultural psychology contributions to the psychologist's professional training and practice in the context of inclusive education. Psicologia USP, 23(1), 111-132. doi: 10.1590/S0103-65642012000100006

Booth, T. et. al. (2000). Index for Inclusión: developing learning and participacion in schools. Bristol: Center for Studies on Inclusive Education.

Brandes, J. A., Mcwhirter, P. T., Haring, K. A., Crowson, M. H., \& Millsap, C.A. (2012). Development of the indicators of successful inclusion scale (isis): Addressing ecological concerns. Teacher Development, 16(4), 463-88. doi: 10.1080/13664530.2012.717212

Carpenter, Ch., \& Sean, C. (2011). Effect of clinic experience on pre-service professionals perceptions of applied special needs services. Revista Brasileira de Cineantropometria \& Desempenho Humano, 13(2), 145-149. doi: 10.5007/1980-0037.2011v13n2p145

Cologon, K. (2012). Confidence in their own ability: Postgraduate early childhood students examining their attitudes towards inclusive education. International Journal of Inclusive Education, 16(11): 1155-73. doi: 10.1080/13603116.2010.548106

Constitución Española (Boletín Oficial del Estado, 29/12/1978).

Cook, B.G. (2002). Inclusive attitudes, strengths, and weaknesses of pre-service general educators enrolled in a curriculum infusion teacher preparation program. Teacher Education and Special Education: The Journal of the Teacher Education Division of the Council for Exceptional Children, 25(3), 262-77. doi: $10.1177 / 088840640202500306$

Costello, S., \& Boyle, C. (2013). Pre-service secondary teachers' attitudes towards inclusive education. Australian Journal of Teacher Education, 38(4), 8. doi: 10.14221/ajte.2013v38n4.8

De Boer, A., Pijl, S. J., \& Minnaert, A. (2010). Regular primary schoolteachers' attitudes towards inclusive education: A review of the literature. International Journal of Inclusive Education, 15(3), 331-53. doi: 10.1080/13603110903030089

Duek, V. P. (2014). Continued formation: analysis of teaching resources and strategies for inclusive education in the view of teachers. Educação em Revista, 30(2): 17-42. doi: 10.1590/S0102-46982014000200002

European Agency for Development in Special Needs education - EADSNE (2011) Mapping the implementation of policy for inclusive education - an exploration of challenges and opportunities for developing indicators â european agency for development in special needs education. Odense: EADSNE.

Forlin, C., \& Chambers, D. (2011). Teacher preparation for inclusive education: Increasing knowledge but raising concerns. Asia-Pacific Journal of Teacher Education, 39(1), 17-32. doi: 10.1080/1359866x.2010.540850

Forlin, C., I. García Cedillo, S. Romero-Contreras, T., Fletcher, T., \& Rodríguez Hernandez, H. J. (2010). Inclusion in Mexico: Ensuring supportive attitudes by newly graduated teachers. International Journal of Inclusive Education, 14(7), 723-739. doi: 10.1080/13603111003778569

Forlin, C., Loreman, T., Sharma, U., \& Earle, C. (2009). Demographic differences in changing pre-service teachers' attitudes, sentiments and concerns about inclusive education. International Journal of Inclusive Education, 13(2), 195209. doi: $10.1080 / 13603110701365356$

Forlin, C., Sharma, U., \& Loreman, T. (2007). An international comparison of preservice teacher attitudes towards inclusive education. Disability Studies Quarterly, 27(4)

Glumbic, N., Kaljaca, S., \& Brojcin, B. (2004). The attitude of future special educators towards inclusive education of children with mild intellectual disability. Journal of Intellectual Disability Research, 48, 505-05.

Gokdere, M. (2012). A comparative study of the attitude, concern, and interaction levels of elementary school teachers and teacher candidates towards inclusive education. Kuram Ve Uygulamada Egitim Bilimleri, 12(4), 2800-06.

HELIOS II (1996). Carta de Luxemburgo: Hacia una escuela para todos. In Informe Final del II Programa de Acción Comunitaria a favor de las personas con discapacidad Programa Helios II 1993-1996. Luxembourg: European Community.

Jiménez-Monteagudo, M. L., \& Hernández-Álvarez, J. L. (2013). Initial training for inclusive physical education: situation, prospects and competencies. Revista Internacional de Medicina y Ciencias de la Actividad Fisica y del Deporte, 13(51), 471-494.

Kyriacou, C., Avramidis, E., Stephens, P., \& Werler, T. (2013). Social pedagogy in schools: Student teacher attitudes in england and norway. International Journal of Inclusive Education, 17(2): 192-204. doi: 10.1080/13603116.2011.629689

Lambe, J. (2011). Pre-service education and attitudes towards inclusion: The role of the teacher educator within a permeated teaching model. International Journal of Inclusive Education, 15(9): 975-99. doi $10.1080 / 13603110903490705$

Ley 1/1990, de 3 de octubre, de Ordenación General del Sistema Educativo (Boletín Oficial del Estado, 03/10/1990).

Ley 13/1982, de 7 de abril, de Integración Social de los Minusválidos (Boletín Oficial del Estado, 30/04/1982).

Ley 14/1970, de 4 de agosto, General de Educación y Financiamiento de la Reforma Educativa (Boletín Oficial del Estado, 06/08/1970).

Ley Orgánica 2/2006, de 3 de mayo, de Educación (Boletín Oficial del Estado, 04/05/2006).

Ley Orgánica 8/2013, de diciembre, para la mejora de la calidad educativa (Boletín Oficial del Estado, 10/12/2013).

López-Torrijo, M. (1992). La integración escolar. Análisis del desarrollo legislativo. Valencia: Universitat de València.

Mu, K., Franck, L. G. \& Konz, C. (2007). Attitudes of entry level occupational therapy doctoral students towards inclusion for students with disabilities. Australian Occupational Therapy Journal, 54, S66-S73. doi:10.1111/j.14401630.2006.00590.x

Oliveira, M. A. M., \& Souza, S. F. de (2011). Policies for inclusion: study in a State School in Bello Horizonte. Educar em revista, 42, 245-261. doi: 10.1590/S0104-40602011000500016

Orden de 8 de julio de 1971 sobre actividades docentes de los Institutos de Ciencias de la Educación en relación con la formación pedagógica de los universitarios, (Boletín Oficial del Estado, 12/08/1971).

Orden ECI/3858/2007, de 27 de diciembre, por la que se establecen los requisitos para la verificación de los títulos universitarios oficiales que habiliten para el ejercicio de las profesiones de Profesor de Educación Secundaria Obligatoria y Bachillerato, Formación Profesional y Enseñanzas de Idiomas (Boletín Oficial del Estado, 29/12/2007).

Raimundo Martins, C. L. (2014). Inclusive Physical Education: Teachers Attitudes. Movimiento, 20(2): 637-657.

Real Decreto 1125/2003, de 5 de septiembre, por el que se establece el sistema europeo de créditos y el sistema de calificaciones en las titulaciones universitarias de carácter oficial y validez en todo el territorio nacional (Boletín Oficial del Estado, 18/09/2003).

Real Decreto 1393/2007, de 29 de octubre, por el que se establece la ordenación de las enseñanzas universitarias oficiales, del Ministerio de Educación y Ciencia (Boletín Oficial del Estado, 30/09/2007).

Resolución de 17 de diciembre de 2007, de la Secretaría de Estado de Universidades e investigación, por la que se publica el Acuerdo del Consejo de Ministros de 14 de diciembre de 2007, por el que se establecen las condiciones a las que deberán adecuarse los planes de estudios conducentes a la obtención de títulos que habiliten para el ejercicio de las profesiones reguladas de Profesor de Educación secundaria Obligatoria y Bachillerato, Formación Profesional y Enseñanzas de Idiomas (Boletín Oficial del Estado, 21/12/2007).

Sandoval Mena, M. (2009). Concepciones de los estudiantes de magisterio sobre la inclusión educativa. Aula abierta, 37(1): 79-88.

Sharma, U., Forlin, C. \& Loreman, T. (2008). Impact of training on pre-service teachers' attitudes and concerns about inclusive education and sentiments about persons with disabilities. Disability \& Society, 23(7): 773-785. doi: 10.1080/09687590802469271

Sharma, U., Forlin, C., Loreman, T., \& Earle, C. (2006). Pre-service teachers' attitudes, concerns and sentiments about inclusive education: An international comparison of the novice preservice teacher. International Journal of Special Education, 21(2): 80-93.

Sharma, U., Moore, D., \& Sonawane, S. (2009). Attitudes and concerns of preservice teachers regarding inclusion of students with disabilities into regular schools in pune, India. Asia-Pacific Journal of Teacher Education, 37(3): 31931. doi: 10.1080/13598660903050328.

Silva, M. O. E.da (2013). Research Data in Education and in Visual Arts: contribution for the construction of the Inclusive School. Revista Lusófona de Lusófona de Educação, 25.

Stella, C. S. C., Forlin, C., \& Lan, A. M. (2007). The influence of an inclusive education course on attitude change of pre-service secondary teachers in Hong Kong. Asia-Pacific Journal of Teacher Education, 35(2), 161-79. doi: 10.1080/13598660 
Tetreault, S., Deschenes, P. M., Freeman, A. et al. ((2012). Collaboration stories: preconditions for the improvement of school experiences for children with special needs. In Proceedings of the INTED2012:International Technology, Education and Development Conference (pp. 6089-6097). IATED.

Tiana, A. (2013). Los cambios recientes en la formación inicial del profesorado en España: una reforma incompleta. Revista Española de Educación Comparada, 22, 39-58.

UNESCO (1994). The Salamanca statement and framework for action on special needs education. Paris: UNESCO

UNESCO (2008). 48th session of the international conference on education. Inclusive education: The way of the future. Genova: UNESCO.

United Nations (UN). (2006). Convention on the Rights of Persons with Disabilities. Ney York: United Nations.

Vieira, F. B. A de, \& Martins, L. A. R. (2013). Formation and creativity: elements implicated in the construction of an inclusive school. Revista Brasileira de Educação Especial, 19(2), 225-242. doi: 10.1590/\$1413-65382013000200007

Vitalino, C. R. (2007). Analysis of the need for a bachelor degree professor's pedagogical preparation to deal with the special need student's inclusion. Revista Brasileira de Educaçao Especial, 13(3): 399-414. doi: 10.1590/S141365382007000300007

Warnock, M. (1978). Special Educational Needs. Report of Comité of enquiry into the education of handicapped childrem and young people. London: Her Majesty's Stationery Office. 